\section{7b ERGONOMIC ASSESSMENT OF ARC WELDING JOB}

Somnath Gangopadhyay. University of Calcutta, Kolkata, India

\subsection{6/oemed-2018-ICOHabstracts.229}

Introduction Among the various process of welding metal arc welding is the most common, versatile and inexpensive one and account for over $50 \%$ of the total welding in advanced countries and over $80 \%$ in India. A large number of workforces around the world earn their livelihood in this occupation. Welders have no fixed work station in developing world irrespective of industries. They are forced to work in cramped space assuming awkward posture that burden to cardio-respiratory system.

Methods This study was performed on worker $(n=31)$ engaged in welding job in different unorganised industry throughout West Bengal. The task was examined in the light of the observed physiological parameters and postural load in workers during their performances. The physical strain in terms of cardio-acceleration and energy cost was examined by Heart Rate Monitor. Ergonomic assessment tool REBA (Rapid Entire Body Assessment) was used to assess the working posture and risk level of postural load. Different thermal factors like Dry bulb temperature(DB), Wet bulb temperature(WB), Globe temperature(GT), Relative humidity(RH), Air velocity (AV), Wet bulb globe temperature(WBGT) was evaluated by Asman Hygrometer and EXTECH HT30, KATA Thermometer.

Result Cardio-acceleration and energy cost was found to be moderately heavy. Risk level of postural load was found to be 4-9 category. DB $\left(32.27^{\circ} \mathrm{C}-35.7^{\circ} \mathrm{C}\right)$, WB $\left(23.92^{\circ} \mathrm{C}-26.5^{\circ} \mathrm{C}\right)$, $\mathrm{GT}\left(36.73^{\circ} \mathrm{C}-40.73^{\circ} \mathrm{C}\right), \mathrm{RH}(43.27 \%-49.9 \%), \mathrm{AV}(15.56$ metre/ minute-26.67 metre/minute), WBGT $\left(27.23^{\circ} \mathrm{C}-30.2^{\circ} \mathrm{C}\right)$ was found.

Discussion Postural load was seen to be in the higher order indicating the workers are suffering from huge amount of ergonomic challenges. It can be seen that the welders how encounter with radiant heat sourced from climate as well as from the job itself, which makes the work for the welders more strenuous. It is important to consider both the environmental issues and postural load because they impact the workforce welfare and consequently the productivity.

\section{C RELIABLE RISK PERCEPTION FOR PROMOTING PREVENTION AT CONSTRUCTION SITES}

Krishna Nirmalya Sen. Larsen and Toubro Limited, Kolkata, India

\subsection{6/oemed-2018-ICOHabstracts.230}

Introduction Frequency rates of severe injury including fatality as well as occupational diseases are notably higher in construction than other industries. Studies also indicate that safety performance of construction industry gets adversely affected due to various factors including inherent nature of high risk activities, deployment of large number of unskilled people, heavy machinery as well as demographic factors.

India, with nearly 1.3 billion population, tremendous ethnic and linguistic diversity, high ratio of younger people, is poised for all-round growth. With focus of development of infrastructure, construction sector is the one which is going to boom and sustain the same for several years.
Construction workers keep moving from one place to the other to pursue their profession. Prior to joining the trade, a miniscule of them receive some formal skill training and safety training which are essential for safe working. Consequently a large portion of them get set to pick-up the trade-skills onthe-job, which compounds the challenges to ensuring a safe working at site.

Methods In this study, spanning over 24 months duration, involving more than 10000 workers from multiple project sites, factors associated with 'risk perception', emerges as one of the most common causative contributors for various recordable injury cases. ${ }^{2}$

Results The study highlights that, misplaced risk perception by the individuals associated with the activities at various levels, have acted as the 'trigger', directly or indirectly, leading the event chain to injury outcome.

Conclusion Subsequently, focused efforts are planned for mitigation, by improving risk awareness among all concerned team members, through various methods, including on-the-job, class-room training and experiential learning associated with activity related hazards and consequences.

This paper describes facets of risk perception, its role in risk mitigation and demonstrate effectiveness of awareness programs as well as other initiatives in optimising risk perception for incident prevention.

\section{7d ACCIDENT PREVENTION IN CONSTRUCTION INDUSTRY - PERSPECTIVE OF WOMAN PROFESSIONAL}

Preety Gupta. Independent Professional Consultant, Goa, India

\subsection{6/oemed-2018-ICOHabstracts.231}

Introduction Construction, one of the fastest growing industries in the world, is still considered to be largely male dominated. The common exception being women as civil labourers, in the unskilled category, as seen in several Indian construction sites. Of course, there are examples of women trailblazers globally who are striving to bring about a cultural change and promote diversity and inclusivity throughout the industry. However their numbers are not very high.

Organisation like National Association of Women in Construction (NAWIC) and SEWA have also emerged as a contributory factor in bringing about the transformation.

Methods Exploring examples of companies encouraging engagement of women employees in Construction. Studies show that in the last decade, companies have increasingly been supporting women in construction as an essential element while striving to to grow their business and construction capabilities.

Results Career opportunities for women professional in construction are not limited to engineering and hard core mechanical work. Attributes of women professionals, best suiting certain roles in occupational safety and health at construction sites, aiming to excel in accident prevention safety training.

Conclusion To handle the unique challenges of construction industry, well mix of men and women professionals is desirable for optimised use of their respective inherent potential and talent. While both men and women working in construction face many of the same risks, there are some unique issues that are of greater concern to women, best understood and 